\title{
SZEMLE
}

\section{SISA JÓZSEF „KASTÉLYÉPÍTÉSZET ÉS KASTÉLYKULTÚRA MAGYARORSZÁGON A HISTORIZMUS KORÁBAN" CÍMÜ, AZ MTA DOKTORA CÍMÉRT BENYÚJTOTT ÉRTEKEZÉSÉNEK VITÁJA*}

\author{
AZ ÉRTEKEZÉS TÉZISEINEK ÖSSZEFOGLALÁSA
}

\section{A KUTATÁSI FELADAT ÉS ANNAK ELŐZMÉNYEI}

Az értekezés a historizmus korának (1840-1914) magyarországi kastélyépítészetéről és kastélykultúrájáról kíván elsőként beható és részletes feldolgozást nyújtani.

A historizmus korszakát - a szabadságharc és az abszolutizmus közjátékát is beleértve - összességében gazdaságilag a gyors fejlődés, az iparosodás és a gyarapodás, társadalmilag a városiasodás, a polgárosodás és a demokratizálódás jellemezte. A folyamatok abba az irányba hatottak, hogy az építészet fó színtere egyre inkább a város, $\mathrm{s}$ vezető müfaja a világi középület és a városi lakóház legyen. A kastély azonban, ha nem is tarthatta meg korábbi kiemelt pozícióját, az építészeti múfajok hierarchiájában ezután is fontos szerepet kapott, ami indokolja, hogy beható vizsgálat tárgya legyen.

A kastély tovább élő jelentősége arra vezethető vissza, hogy a még mindig jelentős gazdasági és politikai hatalommal bíró arisztokrácia, illetve nemesség ragaszkodott hagyományos életformájának fenntartásához, sőt soraikat a megnemesített és a szokásaikat átvevő újgazdagok is gyarapították. A kastély különleges la-

\footnotetext{
* A nyilvános vita 2006. január 13-án folyt. A Bíráló Bizottság elnöke Marosi Ernő, tagjai Galavics Géza, Gergely András, Horler Miklós, Koppány Tibor, Kubinszky Mihály és Passuth Krisztina voltak, titkára Lővei Pál volt. A hivatalos bírálók Gyáni Gábor, Komárik Dénes és Winkler Gábor. Az értekezés téziseit, Komárik Dénes opponensi véleményét és a véleményekre adott választ közöljük.
} 
kásformát képviselt. Az egyéni elképzelések megvalósításának ideális eszköze volt: a személyes igények, az ízlés - vagy éppen annak hiánya -, a múveltség, a külföldi tapasztalatok, valamint a rendelkezésre álló anyagi erő más építészeti múfajban elképzelhetetlen kombinációt alkotott. A historizmus korában, amikor a stíluspluralizmusnak, az előképeknek, a „történeti emlékezésnek” kiemelt szerep jutott, a körülmények ennél kedvezőbb találkozása szinte alig képzelhető el. A személyes jelleg érvényesülésének tág teret adott az is, hogy a tulajdonos kezét nem kötötték meg építészeti és szépészeti előírások, engedélyezési eljárások, így a lehető legnagyobb szabadsággal rendelkezett lakhelyének kialakításában. A szorosan vett gyakorlati rendeltetésén túl a kastély mindig betöltött jelképes szerepet is: jelenléte, építészeti kialakítása urának hatalmát szimbolizálta. Mindezen körülmények jóvoltából nemegyszer sajátos építészeti formák, az építészeti müfajra különlegesen jellemző stílusvariánsok kerültek előtérbe, melyek egy része idővel a városi építészetbe is utat talált magának.

A kastély egyik elsődleges funkcióját az egyéni és a családi reprezentáció megjelenítése adta, ami az épület külsejében és belsejében is megnyilvánult. De legalább ilyen fontos volt, hogy a kastély bútorzata, berendezése, müszaki felszerelése révén kellemes lakhely legyen. Mindig is a berendezés részét képezték, de önálló értéket is képviseltek a múkincsek, a különféle gyüjtemények. A kastélyok szerepe e tekintetben egyáltalán nem lebecsülendő, még akkor sem, ha a 19. század második felét mint a múzeumfejlesztés és -specializálódás klasszikus korszakát tartjuk számon. Ugyanakkor a kastély akár a tulajdonos, akár a vendégként ott tartózkodó múvész jóvoltából hagyományosan múalkotások létrehozásának is színhelye volt. Ezenkívül a kastélykert vagy -park mint müalkotás, továbbá mint a kertészképzés, illetve a kertkultúra központja a historizmus korában továbbra is jelentős tényezőnek számított. Ezen előzetesen kialakított és a külföldi példák nyomán is leszürhető elképzelések adták meg az alapját annak, hogy az értekezésben a magyarországi kastélyépítészet szóban forgó korszakának részletes feldolgozásába fogjunk.

A kutatás első, alapvető feladatának a szóba jöhető emlékek számbavétele, azonosítása mutatkozott. A munka kezdeti nehézségét az jelentette, hogy a szóba jöhető kastélyépületek száma összességében igen nagy, továbbá hogy a historizmus emlékeit a közelmúltig a korszakot sújtó előítélet miatt kevés figyelemre méltatták, így az építészettörténettel foglalkozó szakemberek előtt is nagyrészt ismeretlenek voltak. Vagyis először a vizsgálat tárgyát képező épületek körét kellett behatárolni, éspedig - történeti jellegű vizsgálódásról lévén szó - nem a mai, hanem a történelmi Magyarországon. Ehhez egyrészt széles körü forrásfeltárást, másrészt a kastélyok minél nagyobb számának bejárását kellett előirányozni.

Az előzetes elképzelés az egyes kastélyok történeti kutatásán kívül valamilyen mértékben az építtető személyes viszonyainak, a család történetének legalább 
részleges feltárását is célba vette. Ugyanakkor a kastélyok enteriőrjeire és gyüjteményeire, valamint az épületek környezetére is figyelmet szándékoztunk fordítani. Vagyis nem pusztán a kastélyok építésének építészeti elemzése volt a cél, hanem létrejöttük körülményeinek vizsgálata, a mögöttük álló személyes háttér felderítése, illetve a kastély mint összmúvészeti alkotás, egy életforma kereteit nyújtó miliő komplex elemzése. Az általános összkép megrajzolása nyomán pedig a kastély helyét a korszak magyar kultúrájának egészében szándékoztunk elhelyezni.

A nemzetközi szakirodalom a historizmus kastélyépítészetének és kastélykultúrájának sok aspektusát tárgyalta már, előképeket és bátorítást adva egy hasonló magyarországi vállalkozáshoz. Hagyományos építészettörténeti munkák sora taglal olyan kérdéseket, mint a stílus, az alaprajz, a technika vagy a tulajdonképpeni építéstörténet, melyek további vizsgálódások alapját képezhetik. A feldolgozások egy csoportja komplex módon vizsgálja a kastélyépítészet és a kastély-életforma összefüggéseit - az angol Mark Girouard könyvei ebben példamutatók -, szociológiai jellegü munkák tárják fel a kastélytulajdonosok és a velük egy fedél alatt élő személyzet napi életét. A vizsgálatok immár kiterjednek a kastély, a hozzá tartozó múhelyek és gazdaság hétköznapi tárgyaira is. A kastély mint a múkincsek és gyüjtemények őrzőhelye ugyancsak figyelemben részesül, az épületikonológiai megközelítés egyik lehetséges formája pedig az uralmi szimbolika vizsgálata. Újabban több munka foglalkozik az I. világháború előtti aranykor elitjének életformájával, illetve speciálisan a nemzetközi színtéren oly sokat szereplő, kastélyépítésben is jeleskedő újgazdag amerikai és európai családok építőtevékenységével.

Magyarországon a kastélykutatás hagyományosan a korábbi korokra koncentrált és leginkább a szorosan vett építészeti szempontokat vizsgálta, bár egyes áttekintő művek - például Rados Jenő, Biró József vagy Kelényi György alapvető munkái - valamilyen mértékben kitértek a 19. század végi épületekre és kultúrtörténeti kérdésekre is. Az intenzívebb érdeklődés azonban csak a közelmúltban fordult a historizáló kastélyépítészet felé. Ez többféle formában nyilvánul meg. Egyes historizáló kastélyépületekről kisebb-nagyobb monográfiák készültek - többük a jelen értekezés szerzőjének tollából született -, más épületeket műemléki dokumentáció formájában dolgoztak fel. Az enteriőrmüvészet néhány korabeli emlékére is ráirányult már a figyelem, és a korszak arisztokrata mügyüjtése - amely a kastélykultúra egyik lényeges alkotóeleme - szintén felkeltette egyes kutatók érdeklődését. A historizmus korának egy-egy kastélyparkjáról is írtak rövid összefoglalókat, bár a korszak fejlett kertkultúrájának egészéről csak most alakulnak ki első elképzeléseink. Újabban lexikonszerü feldolgozások indultak meg Magyarországon és a környező országokban. Ez utóbbiak „korszaksemlegesek” lévén minden kor kastélyépületeinek figyelmet szentelnek, ám feladatuk elsősorban adatközlés és állapotfelmérés, nem pedig a művészettörténeti elemzés és értékelés. A szóban forgó igen hasznos vállalkozások ugyanakkor még kezdeti stádiumban tartanak: a 
Magyar kastélylexikonnak eddig csak öt kötete jelent meg, mindegyik egy-egy megyét tárgyalva, a Felvidéki kastélyok lexikona két eddigi kötete pedig mindössze a nyitrai kerülettel foglalkozik; befejezésük több évtizedes program lesz.

A jelen értekezés megírását nagyban segítette, hogy a historizmus építészetének általános kutatása Magyarországon az utóbbi két-három évtizedben rohamléptekben halad előre. Szakcikkek, kiállításkatalógusok, építészmonográfiák, összefoglalások egész sora született. Ezen munkák egyes adataikkal a korszak kastélyépítészetének feldolgozásához támpontot nyújtottak, az összkép gazdagításával pedig az általános tájékozódást tették könnyebbé.

\section{AZ ANYAGGYÜJTÉS ÉS A FELDOLGOZÁS}

Az értekezés elkészítésének érdekében az anyaggyüjtés az írott, a nyomtatott és a képi források széles csoportjának feltárására irányult. Legproblematikusabbnak az építtető családok levéltárának a kutatása bizonyult. Ezek jelentős hányada elpusztult; ami fennmaradt, azt részben a Magyar Országos Levéltár őrzi Budapesten, részben vidéki vagy határon túli levéltárakban található. A témával évtizedek óta foglalkozva számos kastély beható levéltári kutatását végeztük el, aminek az adatait korábbi cikkekben jelentettük meg, illetve - az új eredményekkel gazdagítva - az értekezésbe belekerültek. Egyes kastélyoknál töredékes vagy éppen semmiféle iratanyag nem maradt fenn; más épületeknél sejthetők további írott archiváliák, de a továbblépés lehetősége egyelőre a jövőre marad. Minthogy a levéltári kutatás soha le nem zárható, hatalmas munka, különösen egy nagy, átfogó téma esetében, ebben az irányban továbbfejlesztésre mindig lesz mód. A kastélyt tervező építészek levéltári hagyatékával az építtetőkénél talán még mostohábban bánt a sors. Szerencsére a legjelentősebb kastélyépítész, Ybl Miklós tervhagyatéka fennmaradt, akinek a disszertációhoz valamennyi fontos kastélyterve feldolgozásra került. A kutatás során a szorosan vett építészettörténeti gyüjtemények közül a Magyar Építészeti Múzeum anyagából is volt mód meríteni.

Az írott és tervrajzi források mellett mennyiségük és sokrétűségük miatt alapvető jelentőségűek a képi források; sokszor az archív képek az egyetlen fellehető dokumentumai egy-egy épületnek. A jelen munkához ezek minél szélesebb körü feltárására törekedtünk. Kiemelt fontosságúak azon fényképek, melyeket Klösz György a 19. és 20. század fordulóján számos kastély külsejéről és belsejéről készített, s melyek nagyrészt fennmaradtak a Magyar Nemzeti Múzeum Történeti Fényképtárában negatívok, a Budapest Főváros Levéltárában nagyítások, illetve albumok formájában. A századfordulótól kezdve a kastélyokról nagy számban készültek képeslapok is. Kastélyt ábrázoló képeslapokból gróf Teleki Sándorné az I. világháború előtt különlegességszámba menő gyüjteményt állított össze, amely 
szerencsére ma az Iparmúvészeti Múzeumban kutatható. Mindezen képi forrásokat a feldolgozáshoz igénybe vettük. De néhány más közgyűjtemény képeslapanyagában ugyancsak volt alkalmunk kutatni: így az Országos Széchényi Könyvtár Plakát- és Aprónyomtatványtárában, a szerencsi Zempléni Múzeumban és a kolozsvári Egyetemi Könyvtár Különgyűjteményében. Sikerült egy kastélyokra szakosodott magánkollekció, éspedig Cházár László boulogne-i képeslapgyüjteményének darabjait is feldolgozni és lefényképezni. A más múzeumokban őrzött, illetve a kereskedelmi forgalomból folyamatosan köz- és magángyüjteményekbe kerülő képeslapok a kutatásnak ez irányban a távoli jövőben is további lehetőséget ígérnek.

A képi források körébe is sorolhatók, de szövegük miatt ennél még többet nyújtanak az egyes korabeli képes folyóiratok. Ilyen a Budapesti Látogatók Lapja (1888-1896), a Magyarország és a Nagyvilág (1896-1900) és a Szalon Újság (1900-1913), melyek - szinte egyetlen hatalmas folyamot alkotva - egyre inkább a kastélyokra és a kastélyéletre specializálódtak. Az általános jellegű folyóiratok, elsősorban a Vasárnapi Ujság (1854-től) is sok szöveges és képes beszámolót tartalmaz kastélyokról. Hasonló módon fontosak az építészeti szakfolyóiratok, leginkább a két (több címváltozáson átesett) német, illetve magyar nyelvű orgánum: a Budapester Bauzeitung (1874-1875), a Bauzeitung für Ungarn (1876-1896) és az Ungarische Bauzeitung (1896-1914), illetve Az Epitési Ipar (1877-1886) és az Épitő Ipar (1887-1913). A felsorolt periodikumok összes évfolyamát a kastélyépítészet szempontjából feldolgoztuk. Ezen kívül természetesen több más korabeli folyóirat és újság híradását és képanyagát ugyancsak felhasználtuk.

Mind képeit, mind szövegét tekintve igen nagy forrásértékủ a millennium körül megjelent Magyarország vármegyéi és városai című (leginkább Borovszky Samu nevével fémjelzett), be nem fejezett sorozat, amely a történelmi Magyarország vármegyéinek mintegy harmadát mutatja be. Ezek valamennyi kötetét feldolgoztuk, akárcsak számos más egykorú és későbbi helytörténeti munkát. Több esetben támaszkodhattunk a múemléki felújításokkal kapcsolatban készült műszaki dokumentációkra is.

Minthogy Magyarországon a kastélyok a történelem viharaiban sokat szenvedtek és a legtöbb épület mai állapotában csak árnyéka egykori önmagának, eredeti állapotuk meghatározásában az archiváliáknak kiemelt szerep jut. Emellett azonban a meglévő épületek helyszíni vizsgálata sem nélkülözhető, hiszen helyszíni tapasztalatok, személyes megismerés nélkül nehéz hiteles elemzést végezni. Az elmúlt majd három évtized során, és különösen rendszeresen az utóbbi években, számos kastély bejárására került sor. Ez részben a Magyar Tudományos Akadémia Múvészettörténeti Kutatóintézet topográfiai programja keretében történt meg, részben az intézet más formában történt támogatásával, valamint családi és baráti kirándulások alkalmával. A határon túli kastélyokat nagyrészt a Magyar Tudomá- 
nyos Akadémia által a Szlovák Tudományos Akadémiával, illetve a Román Tudományos Akadémiával kötött egyezmények keretében láthattuk személyesen. Néhány kastély beható feldolgozására múemléki tudományos dokumentáció készítésével került sor.

A szakirodalom és ugyancsak helyszíni látogatások segítségével nemzetközi összehasonlításokat is végezhettünk. A historizmus kastélyépítészetét mód nyílott Ausztriában, Csehországban, Németországban, Franciaországban, Nagy-Britanniában és az Egyesült Államokban tanulmányozni. Ez részben magán, részben intézményes keretek között történt. Külön kiemelendő az erre szakosodott külföldi tanfolyamok szerepe, melyeken részt vehettünk: Attingham Summer School (NagyBritannia, 1983), Victorian Society Summer School (Nagy-Britannia, 1996), Victorian Society Summer School (Egyesült Államok, 1999).

A hagyományosabb építészettörténeti munkákkal szemben az értekezésben a kastélyt nem pusztán építészeti alkotásként szándékoztunk kezelni, hanem tágabb összefüggésben. Az építéstörténet, az építési technikák, az architektúra és az alaprajzok elemzése mellett tehát szót kívántunk ejteni az egykor a kastélyokban rejlő enteriőrökről és gyüjteményekről, a szükebb és tágabb környezetről - a kertekről, a parkokról és melléképületekről -, az építtetők személyéről, a kastélyokban zajló életről, a múvészetekről és a tudományról. Úgy véltük, a kastélyépítészet nem választható el a kastély használatától, általában a kastélykultúrától, a tisztán építészeti analízis helyett a komplex megközelítés teszi lehetôvé a kastély mint jelenség lényegének megértését.

\section{AZ ÉRTEKEZÉS FELÉPÍTÉSE ÉS TUDOMÁNYOS EREDMÉNYEI}

A kutatás során mintegy 600 historizáló és századfordulós kastélyépületet regisztráltunk a történelmi Magyarország területén. Jó néhány további épület is a látókörbe került, de ezeket megbízható adatok híján egyelőre nem vettük fel a jegyzékbe. Valószínú, hogy a jövendő e tekintetben nem kevés pontosítást és kiegészítést tesz majd lehetővé. Ugyanakkor a regisztrált épületek közül soknál a pontos adatok nem ismeretesek: az építési időpont csak hozzávetőlegesen állapítható meg, az építész neve ismeretlen, a kivitelezés körülményeiről sem lehet tudni. A jövőbeli kutatás a következő évek-évtizedek során nyilván jó néhány épületről sok mindent ki fog deríteni. Azonban az is valószínűnek látszik, hogy a dokumentumok pusztulása miatt sokuknál, talán a többségüknél ezek az adatok soha nem fognak előkerülni. Mindamellett úgy véltük, elégséges adat és ismeret áll már rendelkezésre ahhoz, hogy az első, remélhetőleg hiteles összefoglalás a témáról akadémiai doktori értekezés formájában megszülessen. 
A munka két fő részből áll: általános áttekintésből és elemzésből, valamint fontos vagy tipikus kastélyok hosszabb-rövidebb monografikus szócikkéből, vagyis az első rész általános jellegű tematikájához illeszkedő, kronologikus rendbe állított miniatür esettanulmányok füzéréből.

Az építtetők személyével kapcsolatban megállapítható, hogy az uralkodó és családja a kastélyépítészet területen viszonylag csekély szerepet vállalt. Mintaadónak az arisztokrácia számított, ahol egyes családok - pl. a Károlyiak és az Andrássyak - rendkívüli kastélyépítő tevékenységet folytattak, amit egyebek közt a nagykárolyi és a tiszadobi kastély bizonyít. Mellettük az 1870-es évektől szép számban tủntek fel a polgári származású és hasonulni vágyó újgazdagok, hogy a századforduló legnagyobb kastélyát már Törley József pezsgőgyáros építse fel Budafokon. A kastély tervezése és kivitelezése a többi építészeti múfajhoz képest számos specifikumot mutat, nem utolsósorban az építtetők személyes viszonyulása és aktív - néha amatôr tervezői, sőt munkavezetői - közremüködése miatt. Erre példa a füzérradványi kastélyának csenevész tornyát megtervező gróf Károlyi Ede, aki saját, ez irányú szerepét a falu templomának oltárképén is megörökíttette. Néhány jeles építésszel divat volt kastélyt terveztetni - ilyen volt elsősorban a legtöbbet foglalkoztatott mester, Ybl Miklós vagy Hauszmann Alajos, illetve a kastélyépítész-specialistának számító Meinig Arthur -, de számos jelentéktelen magyar vagy külföldi építész kapott még hasonló megbízatást, akik megbízóik kívánságait vagy éppen szeszélyeit szolgai módon követték. A bécsi Friedrich Flohr vagy Moritz Wappler építészi munkássága például a Magyarországon emelt kastélyukon kívül jóformán megfoghatatlan.

A stílusok tekintetében a kastélyépítészet a városi építészettel szemben külön utakon is járt: az angolos neo-Tudor romantika alkalmazásában úttörő a szerepe, ezt követően a franciás stílusvariánsok domináltak. Mellettük az olasz neoreneszánsz viszonylag háttérbe szorult; a jelek szerint a történeti asszociációi miatt a polgári származású építtetők kedvelték inkább. 1900 körül és után a szecessziós és egyéb századfordulós áramlatok virágoztak, ám mellettük a történeti stílusformák intenzív továbbélésének lehetünk tanúi.

A konfiguráció és a tömegalakítás tekintetében általában a mozgalmasság jellemzi a kastélyépítészetet, ami újdonságot jelent a klasszicizmus fegyelme után. Számos kastély alaprajzát és téralakítását megvizsgálva több új vonás ragadható meg. A közösségi termek gyakran a korábbi sémától eltérve szabálytalanul vagy több traktusban helyezkedtek el. A rugalmasabb megoldást elösegítette a technikai fejlődés, az üvegezett felülvilágító alkalmazása. Új térként megjelent a kétszintes csarnok, amely utóbb nem egyszer a közösségi élet központjának számító szalon szerepét is átvette. A historizmus korában a kastély meglehetősen tagolt és specializálódott építmény volt: a közösségi és díszterek, a családi lakosztályok, a vendégszobák, a személyzet helyiségei, valamint a raktárak és üzemek jól elkülönült, 
de egymást logikusan kiegészítő egységeket alkottak. Megfigyelhető, hogy a családi lakosztályokban a férfi és a női részleg továbbra is kettévált, mint ahogy a közösségi termek egy részének is megvolt a nemekhez köthető specifikus jellege. Kisebb kastélyoknál a differenciálódásnak természetesen kevesebb tér nyílt.

A historizmus és a századforduló korszakában az anyagi kultúrát a rendkívüli mennyiségi gyarapodás és minőségi sokrétűség jellemzi, ami a kastélyok enteriőrkialakításában ha lehet, még fokozottabban érvényesül. A fejleményeket leginkább a faburkolatok és a textíliák kedvelésével, az erőteljes és mélyülő színvilág alkalmazásával, a nehéz, „,neostílusú” bútorok kötetlen formában történő elhelyezésével, a fülledt „makartizmus” térhódításával lehet jellemezni. Emellett egyre fontosabb a kényelmi igények kielégítése, legyen szó párnázott és rugózott bútorzatról vagy a rohamosan fejlődó épületgépészetnek a kastélyokban hamar megjelenő vívmányairól. A komfort az európai civilizációban viszonylag új fogalom, és a historizmus korában a lakóhelyek belső kialakításának egyik vezéreszméje volt. A századvég fejleménye, hogy a kastélyokban megjelennek az erre szakosodott lakberendező cégek, mint a keszthelyi Festetics-kastélyt felszerelő bécsi Portois és Fix, vagy a Magyarországon is lerakatot nyitó Schmidt Miksa-féle vállalat. Az ábrahámi Esterházy-kastélyban pedig Josef Urban jóvoltából a bécsi szecesszió érzékeny összművészeti alkotása jött létre.

A kastélyhoz különféle rendeltetésű, nagyságú és külsejű melléképületek tartoztak. Bár a kastély ebben a korban is még rendszerint uradalmi központ, ez ekkor már nem jelenti azt, hogy a fóépület közelébe gazdasági épületek kerültek volna; a 19. század második felében a kastélyok - amennyire lehet - elkülönültek a gyakorlati élettől, és jellemzően a település határában vagy még inkább azon kívüli elszigeteltségben emelkedtek. Kivételt képeztek egyes újgazdagok kastélyai, melyek alkalmanként jól látható helyen, néha - a tulajdonos jelenlétét és fennhatóságát is reprezentálandó - gyáruk közvetlen közelében épültek.

A kastélyok parkjaiban egyre inkább megjelennek vegyes stíluselemek; ahogy az építészetben a század közepén uralkodó angolos modor utóbb a franciának átengedi a teret, a kertmúvészetben is a francia felfogás, a mértanias stílus válik divatossá. Ugyanakkor a historizmus parktervezésének és kertészeti kultúrájának egyik meghatározó eleme a növényzet gazdagodása. Megnőtt a virágok iránti érdeklődés, egyes esetekben a virágkultusz, és divatba jött a különleges fák gyüjtése is. Az uradalmi kertészet ebben a korban is föszerepet játszott, de létrejöttek a kereskedelmi kertészetek, illetve a kertészeti irodák és vállalatok. Az egyik első és legnagyobb ilyen intézményt a 19. század végén a német születésű Hein János alapította, aki a park létesítésével kapcsolatos valamennyi tevékenységet elvégzett.

Az értekezésben az általános építészeti elemzéssel együtt a vonatkozó társadalomtörténeti és múvelődéstörténeti aspektusok összefogó tárgyalására is sor kerül. Szó esik a tulajdonosok napi rutinjáról éppúgy, mint a szórakozásáról - kiemelten 
a kastélyokhoz legszorosabban kötődő, legnépszerúbb időtöltésről, a vadászatról -, illetve a kastélyok használatának évszakonkénti váltakozásáról. Az utóbbinál megfigyelhető a korábbi szokások megváltozása, a kastélyszezon év végéig történő kitolódása. Az életforma vizsgálata nem csupán a tulajdonosra és családjára terjed ki, hanem az őket kiszolgáló személyzetre is, belső hierarchiájukra, kastélyon belüli és kívüli lakhelyükre. Az ilyen irányú elemzés az épületek alaprajzi rendszeréből levonható tanulságokon kívül egykorú ábrázolásokra és leírásokra, továbbá memoárokra és irodalmi alkotásokra támaszkodik.

A kastély a historizmus korában is a múvészetek - festészet, irodalom, zene, színjátszás - otthona, de jelentősége a korábbi korokhoz képest csökken; szerepét leginkább a „múkedvelő” és a „perifériális” jelzőkkel lehet leírni. Viszont továbbra is a magánműgyüjtemények alapvető őrzési helyének számít, legyen az a minden irányban érdeklődő gróf Pálffy János Magyarországon példátlan gyüjteményfüzére - ennek egyik elemeként épült meg a hatalmas bajmóci kastély -, vagy a tiszadobi kastélyban helyet kapó és mintaadóan modernnek számító ifj. Andrássy Gyula-féle festészeti kollekció. A disszertációban külön figyelmet kap a reprezentáció kérdése, a kastélyoknak a fényképezés jóvoltából robbanásszerú ismertté válása, valamint a nyilvánosság dilemmája, a társadalomnak a kastélyok felé irányuló felemás viszonyulása.

Az értekezés központjában maga a kastély áll. Ennek értelmében nem vállalkozhatott teljes részletességü élet- és társadalomrajzra, mint ahogy a birtok- és gazdaságtörténet alapos ismertetésére sem. Az enteriőr- és kertmúvészeti, valamint a múvelődéstörténeti aspektusok behatóbb tárgyalása ugyancsak szétfeszítette volna az értekezés kereteit. A jelen dolgozatban ezek mint a nagy egységet alkotó áttekintés és elemzés résztémái szerepelnek; kétségtelen, hogy teljes kidolgozásuk - majd a kutatás megfelelő stádiumában - önmagában is megér egy-egy önálló disszertációt.

Az értekezésünk második részében bemutatott 83 kastély esetében - még ha kutatásuk nem is azonos mélységben történt meg - rendelkezésre állt annyi adat és helyszíni információ, hogy megfelelő léptékủ tárgyalásuk lehetséges legyen. Kiválasztásuknál fontos volt, hogy lehetőség szerint a korszak kastélyépítészetét kellő mértékben képviseljék a következő alapvető szempontok alapján: az időrendbeni eloszlás; a földrajzi megoszlás; az épület stílusa, mérete, jellege és funkciója; az építtető társadalmi háttere. Az egyes szócikkek nem pusztán adatközlések, még ha a rendelkezésre álló dokumentumok, illetve az abból levonható következtetések természetesen helyet is kapnak bennük, hanem arányos léptékben elemzést és értelmezést is tartalmaznak. Szó van bennük az építtetőről, az építés körülményeiről, a kastély építészeti jellemzőiről, az enteriőrökről - egykorú leírással, ha fennmaradt -, az épület környezetéről és a parkról. A témaválasztásból fakadóan egy-egy szócikk a historizmus korára összpontosít: ahol korábbi kastély 
átépítéséről volt szó, az előtörténettel csak érintőlegesen foglalkozik, és az épület későbbi sorsára sem tér ki, legfeljebb az esetlegesen utóbb bekövetkezett radikális átépítés vagy pusztulás tényét regisztrálja.

Az első és a második rész szövegterjedelme hozzávetőleg egyforma (kb. 9-9 szerzői ív). Ezután következik a szorosan vett adattár, illetve apparátus (kb. 3 szerzői ív). Ez tartalmazza a historizmus korszaka valamennyi azonosított kastélyának alfabetikus jegyzékét az alapadatokkal, a kastélyok jegyzékét vármegyék szerinti bontásban, a kastélyokat tervező építészek rövid ismertetését szintén alfabetikus rendben, továbbá a bibliográfiát, a rövidítésjegyzéket és a képjegyzéket. A közel három évtizedes anyaggyüjtés során a szóban forgó kastélyokról több ezer fénykép gyưlt össze, részben archív fotók, részben helyszíni felvételek. Ezekből válogattuk ki a mondanivalót legjobban illusztráló és témát leginkább reprezentáló 335 képet, melyek az értekezésben szerepelnek.

A historizmus korában virágzó kastélyépítészet és kastélykultúra egy nagy múltú múfaj utolsó fénykorát jelentette Magyarországon. Egy olyan fellobbanást, amelyet több hasonló már nem követhetett. Az 1914 után meginduló történelmi kataklizmák és radikális társadalmi változások merőben új viszonyokat teremtettek, melyek nem kedveztek a további fejlődésnek, sőt utóbb egyenesen a kastélyépületek fizikai létét kérdőjelezték meg. Ha maguk az épületek nagy része mára meg is maradt, tartalmuk - a bútorok, múkincsek, levéltárak, könyvtárak - megsemmisült, a magyar kultúra fájdalmas, soha nem pótolható veszteségeként. A téma feldolgozásával az értekezés remélhetőleg segít abban, hogy az eltűnt világ visszakerüljön a magyar tudományosságba és köztudatba. Gyakorlati hasznosítása leginkább a múemlékvédelemben lehetséges.

\section{A JELÖLT PUBLIKÁCIÓINAK JEGYZÉKE AZ ÉRTEKEZÉS TÉMAKÖRÉBŐL}

A vépi volt Erdődy-kastély Vas megyében. Müemlékvédelem XXI. (1977) pp. 170-172.

Adalékok a magyarországi romantikus kastélyépítészethez. Ars Hungarica VIII. (1980) pp. 103-125.

English Influence on Hungarian Romantic Architecture. The New Hungarian Quarterly XXIII. (1982) 87. pp. 182-185.

Kastélyok közt Nagy-Britanniában. Magyar Építömüvészet LXXV. (1984) pp. 216-225.

Egy eltűnt kastély nyomában (A galgamácsai királyi vadászlak). Müemlékvédelem XXX. (1986) pp. 15-20.

Der Schloßbau in Ungarn im 19. Jahrhundert. Arx, Burgen und Schlösser in Bayern, Österreich und Südtirol IX. (1987) pp. 203-207.

Alois Pichl (1782-1856) épitész Magyarországon. Müvészettörténeti Füzetek 19. Akadémiai Kiadó, Budapest, 1989. 
Kastélyépítészet Magyarországon Ybl Miklós korában. In: Ybl Miklós épitész 1814-1891. Kiállításkatalógus, Hild-Ybl Alapítvány. Budapest, 1991. pp. 141-149.

Landscape Gardening in Hungary and Its English Connections. Acta Historiae Artium XXXV. (1990-92) pp. 193-206.

„Bárki mit mond is, az Architectúra törvényi csupa önkényen alapulnak". Széchenyi István építészeti érdeklődése. Müvészettörténeti Értesitö XLI. (1992) pp. 45-61.

Kastélyépítészet a historizmusban. In: Zádor Anna (szerk.): A historizmus müvészete Magyarországon. Budapest, 1993. pp. 65-78.

A mikosdpusztai Mikos-kastély. In: Gerő László nyolcvanötödik születésnapjára. Tanulmányok. Budapest, 1994. pp. 387-399.

A füzérradványi Károlyi-kastélyszálló. A kastély rövid krónikája. Szalon I. (1997) 1. sz. p. 8.

The 'English Garden' and the Comfortable House. British Influences in Nineteenth-Century Hungary. In: Gyula Ernyey (ed.): Britain and Hungary. Contacts in Architecture and Design During the Nineteenth and Twentieth Century. Budapest, 1999. pp. 71-94.

A füzérradványi kastély. Ars Hungarica XXVII. (1999) 5-78.

A vajdahunyadi vár 19. századi restaurálásáról. Ars Hungarica XXIX. (2000) pp. 97-108.

A nádasdladányi Nádasdy-kastély. Müvészettörténeti Értesitö XLIX. (2000) pp. 21-54.

Az ,angolkert” és a kényelmes ház. Brit hatások a 19. századi Magyarországon. Ars Hungarica XXIX. (2001) 1. sz. pp. 75-110.

Nádasdladány. Nádasdy-kastély. Tájak-Korok-Múzeumok Kiskönyvtára 690. Budapest, 2001.

An Architectural Icon for Hungary: Vajdahunyad Castle. In: Jeremy Howard (ed.): By Force or by Will. The Art of External Might and Internal Passion. St Andrews, 2002. pp. 93-104.

Beke László - Gábor Eszter - Prakfalvi Endre - Sisa József - Szabó Júlia: Magyar müvészet 1800-tól napjainkig. Corvina Kiadó, Budapest, 2002. „Kastélyépítészet a polgárosodó országban” c. alfejezet, pp. 61-65.

A nádasdladányi Nádasdy-kastély. Müemlékek Állami Gondnoksága, Budapest, 2004.

\section{KOMÁRIK DÉNESNEK, A MÜVÉSZETTÖRTÉNETI TUDOMÁNY DOKTORÁNAK OPPONENSI VÉLEMÉNYE}

A most megvitatandó disszertáció szerzője, Sisa József a mintegy fél évszázada fokozatosan kibontakozó hazai épitészeti historizmuskutatás egyik legjelentősebb, legtermékenyebb, kiemelkedő és meghatározó személyisége. E múvészettörténeti munkálkodását a 19. század egészének építészettörténeti vizsgálódásába és a kertmúvészetnek természetesen ezen időtávon túlnyúló territóriumába ágyazva múveli. E munkálkodásával a művészettörténetnek nemzetközi viszonylatban is prioritást élvező olyan építészettörténeti korszakába mélyed el, mely rövid idő alatt a történelemben eddig köztudottan (minőségétől, egyenetlenségétől függetlenül) a legnagyobb mennyiségü alkotást produkálta - mely ugyanakkor azonban szemünk láttára korábban nem sejtett rohamossággal tünik el a föld színérôl.

A Kastélyépitészet és kastélykultúra Magyarországon a historizmus korában címet viselő értekezés a korszak egészéből a historizmus kastélyépítészetének a 
szerző szakirodalmi tevékenységében tapasztalhatók alapján elvárható gazdagságú első összegezése. A mű egyesíti szerzőjének már ott megmutatkozó legszélesebb körű általános tájékozottságát, a műemlékvédelem szolgálatában végzett és folyamatosan készülő kastélymonográfiák révén szerzett jártasságát, tudományos habitusának sajátságait, erényeit; egyszóval kutatói eszköztárának gazdagságát és annak bravúros kezelését.

A világosan, jól felépített értekezés külön megemlítendő sajátsága, hogy a szorosan vett építészettörténet - mind az emlékek tárgyalásánál, mind az áttekintő gondolatmenetek, összefoglalások végigvezetésénél - az azoknak alapjául szolgáló életmód, emberi magatartás, múveltség stb. tüzetes feltárásába és bemutatásába ágyazva jelenik meg. Továbbá természetesen művészetileg hozzáértően kiterjeszkedik a kertépítészetre is, múszakilag az alaprajzi és felépítési konstrukción kívül a növekvő müszaki-gépészeti felszereltségre, hogy csak a fontosabbakat említsem. - A korszakválasztás, pontosabban az életforma viszonylagos azonossága által legitimált korszakhatár-kijelölés teljesen indokolt, mint ahogyan a történetileg adott területi egységre való alapozás is. Minderről és az e sűrített előzetes áttekintésben szereplő témákról és egyebekről természetesen lesz majd szó részletesebben is a továbbiakban.

Eme összefoglaló bevezetés után az érdemi tárgyalást egy tartalmi és egy módszert illető általános megjegyzéssel szeretném kezdeni.

Az értekezés tárgya, mint láttuk, a hazai építészeti historizmus egy kitüntetett területének, a korszak kastélyépitészetének nagyszabású alapkutatása és bemutató áttekintése. Ez azonban a magyarországi építészettörténet egészének szempontjából annak teljes kastélyépítészeti vonulata kidolgozásának belátható időn belül elérhető közelségbe hozásához való jelentős hozzájárulást is jelent. Ennek köszönhetően a korábbi századoknak a középkortól a 18. század végéig terjedő, feldolgozottabb, jobban előmunkált korszakához felzárkózva egy nagyobb egység vízióját vetíti elénk, melynek birtokában a castellumoktól a 20 . század elején megjelenő utolsó példákig az egész folyamat nagy ívét, az abban megnyilatkozó kontinuitást, (olykor diszkontinuitást), egyedi változatai sokrétúségének megragadását nem szükséges immár elérhetetlen távolságban látnunk. Egyebek mellett - hogy csak valamennyit említsek a számos, hasonlóan fontos mozzanat közül - ez különösen érzékelhető Koppány Tibornak bő évtizede megvédett kandidátusi értekezésének számos résztanulmánnyal alátámasztott, valamint Dobrovits Dorottya tragikusan rövid életművének eredményeivel is megerősített anyagából, gondolva az építési gyakorlat igencsak különböző formákat öltő, de magvában analóg jellegére, vagy a különböző okokból és módon itt múködő külhoni építészek stílusközvetítő szerepére. Hogy egyebekről és a 18-19. századi kutatásoknak e folyamatot megelőző és rá következő szakaszával ugyanígy összekapcsolható, de a szükséges különbség- 
tevést is lehetővé tevő jelentős erdményeiről - az önkorlátozás elengedhetetlen parancsának engedelmeskedve - csupán utalásszerüen tegyek említést.

Az értekezésnek túlnyomórészt szerkezetében megnyilatkozó másik sajátságát illető általános megjegyzésem ahhoz kapcsolódik, hogy - miként már röviden említettem - „kettös” szempontú müröl van szó, ami, bár röviden, de szerepel a mü címadásában is. Erről a szerző már a Bevezetés elején szabatosan számot ad, és hangsúlyozza, mondván: ,a szóban forgó épületeknek nem pusztán stiláris vizsgálatát tűztem ki célul, hanem számos más aspektusát, az egész kastélykultúráét is" (5. old.). Bár valóban ezt teszi, és helyesen, egyebek mellett annak következtében is, hogy egy gazdagodással kecsegtetó új szempontot ad a kezünkbe; azért tudnunk kell, azok az épületek - kevés kivétellel - ha olykor csak töredékesen is - mégis csak a historizmus valamilyen árnyalatát, változatát képviselik, egészében pedig, ha ez a megállapítás talán nem teljesen szabatos is, a historizmus világához tartoznak. Hiszen, ne felejtsük, a szerző által magyarázatul elhangzó, a stiláris vizsgálat célkitüzésén túlmutató aspektusoknak (ha olykor csak csíraszerủen) a hagyományosan historizmusnak nevezett későbbi időszaktól lényegesen nem különböző vonásai vannak, valamint a vizsgálódásnak valóban középpontjába állított kastélykultúra számos eleme otthonos volt például klasszicista megfelelőik életében is.

Mindez természetesen nem teszi problematikussá a szerző korszakválasztását, főként nem tagadja az annak szempontjában rejló ígéretet. Csupán a szabatos kontúrozás szükségességének hangsúlyozását, a kontinuitás szem elől nem tévesztésének fontosságát. Hiszen e nagy kezdeményezést, alapozást - reményünk szerint folytatni fogják, $\mathrm{s}$ a tudománytörténet tanúsága szerint egy kisebb vagy nagyobb jelentőségú szempont felmerülése mindig csábítja a folytatókat az egyoldalú, akár monokauzális kezelésre. Félreértések elkerülése érdekében hangsúlyozom, hogy a kezünkben levő értekezés ilyen aránytalanságokat nem tartalmaz. A kétféle feldolgozási módot bő nemzetközi szakirodalmi utalással kísérve részletesebben is megidézi: „Hagyományos építészettörténeti munkák sora taglal olyan kérdéseket, mint a stílus, az alaprajz, a technika vagy a tulajdonképpeni építéstörténet, melyek alapját képezhetik további vizsgálódásoknak.” Ugyanakkor „,a feldolgozások egy csoportja komplex módon vizsgálja a kastélyépítészet és a kastélykultúra kérdéseit, [...] szociológiai jellegü munkák tárják fel a kastélytulajdonosok [...] és a személyzet napi életét, és a vizsgálatok [...] kiterjednek a kastély, a hozzátartozó múhelyek és a gazdaság hétköznapi tárgyaira is". (5. old.) És egyebekre is, de e helyen, ahol az egész írás struktúráját akarjuk jellemezni, nem szükséges ezek tüzetes felsorolása.

Mindehhez, tehát a témaválasztáshoz és a mü kétféle szempontot követő feldolgozási módjához a következőket szeretném még hozzáfüzni.

A 19. század második felének építészettörténetében - a nem jelentéktelen résztanulmányok ellenére is - oly sok a nagy egységek, épület- és építészmonográfiák 
terén a fehér folt, hogy úgyszólván minden témaválasztás indokolt, minden témaválasztás ígéretes. Különösen érvényes (egyben az akadémiai doktori fokozat elnyerésére törekedve arányos léptékű választás) ez monumentális épületek, mint például templomok, székesegyházak, kultikus építmények, paloták és hasonlók esetében. Ezek esetében az ember metafizikájáról van szó: minden monumentális építmény az ember önfelfogásáról árul el valamit. Tehát arról, amit ideái tüznek az ember elé, amivé az ember lenni akar, amit megálmodik. Ezt azonban teljes mértékben kell értenünk - nem individualisztikusan, hanem történetileg, egy közös sajátságokkal, közös ideálokkal és vágyakkal rendelkező emberi közösség értelmében. És ez az, ami oly ellenállhatatlanul vonz bennünket a valódi hagyomány talaján sarjadt, nagyszabású belső stílussal rendelkező építményekhez.

Túl azon, ami az elmondottakból a monumentális épületek világának egészére érvényes és számunkra is kiemelkedően fontos, sajátos, mondhatni a kutatás ,technikáját” illető előny is származik. Nevezetesen az, hogy az említett „,belső stílus” mellett, nem utolsó sorban ennek megléte következtében kibontakozó, ezzel lényegileg egybeforrott - nevezzük ,külső stílusnak” (amin természetesen nem a „snörklik” szövevénye értendő) - stiláris sajátságaival könnyebben boldogulunk. A belső és külső stílust szemlélve ugyanis, azokban elmélyedve, erőteljesebb, gazdagabb forrás birtokában küzdünk meg a mü, annak stílusa elemzésével, interpretálásával, mint tehetnénk az adott korszak sokkal szerényebb alkotásai alapján. Még akkor is, ha ez utóbbiak, miként a Tanagra-figurák, magukon viselik is a nagy stílus jegyeit, formai tendenciáik csíráit.

Itt szeretnék helyt adni a mindnyájunk által ismert tény említésének, hogy hazai monumentális építészetünk a legnagyobb egyetemes példák színvonalát általában nem éri el, ami kiemelkedő van, az is többnyire szerényebb a nemzetközi mezőny rokon múveinél. A monumentális-triviális kettősség azonban fennáll, és általános jellemzésükre is az áll, ami a legnagyobbakra érvényes.

A monumentalitásról szóló iménti egész gondolatmenetnek már elején is bárkinek eszébe juthatott, hogy hiszen nemcsak a monumentális épület, már az egyszerủ lakóház is az ember lényegi sajátosságairól tanúskodik, ha nyilván annak szerényebb, mindennapi rétegeit érinti is csupán. Valóban: minden épület, minden épített környezet aszerint alakul ki, nyeri el formáját, hogy milyen az az életmód, amelynek keretéül szolgál. Az épület milyenségében mindig jelentős szerepe van (volt és lesz is) az életmódnak, az anyagihoz kötődőnek csakúgy, mint a szelleminek.

Nemcsak helyesen járt el a szerző, hanem egy ilyen alapvető, a gyökerekig leásó fundamentumra épülő első nagyszabású tablónál elengedhetetlen követelménynek tett eleget, mikor mindezekkel foglalkozott, éspedig az ennek markáns megragadását lehetővé tevő monumentális műfajt választva feldolgozása tárgyául. Ne felejtsük, sokak által művelendő, sokáig tartó vállalkozás lesz, míg a korszak 
kastélyépítészetének megírása a soha el nem érhető teljességet eléri - hogy paradoxonnal nyomatékosítsam a feladat nagyságát. S jó, ha az értekezésben bőven megmutatott életmódelemek, és amik ezek kielégítéséhez szükségesek, e virtuális vállalkozás forrásánál már jelen vannak, $\mathrm{s}$ ott létükkel figyelembe vételüket mintegy háttérismeretként elevenen tartják. Még akkor is, ha az egyes munkálatok ezeket - természetes módon - a legkülönfélébb mértékben és jelleggel fogják érvényesíteni.

A szerző felvet egy valóságos, de eddig nem túlságosan (vagy tévesen) feszegetett összefüggést is a fő kastélyépítő rétegnek, az arisztokráciának (nyugodtan hozzátehetjük a súlyában szerényebb, de számszerüségében akár terjedelmesebb kastélyépítő köznemességnek is) tradicióban élő mentalitását, valamint az építésben, így a kastélyépítésben is akkor általánosan érvényes historizálást. Hogy az utóbbi az előbbinek következménye lett volna, nem állíthatjuk, de a kettő találkozásának mint jelenségnek leírásával, analizálásával, elméleti értékelésével még alapjában adósak vagyunk. A disszertáció áttekintő, részletes feltáró összképe a maga terjedelmes kazuisztikus anyagával mindezek megválaszolására is lehetőséget kínál, aminek elvégzése természetesen nem volt e dolgozat feladata.

A nem is sejtett mélységü és szövevényességü problematikáról csak annyit, hogy az arisztokrácia tradícióérzékenysége és -közelsége, a historizmussal való látszólagos benső kapcsolata, netán kongenialitása (lévén ez utóbbi is „Stilarchitektur") nemcsak nem áll fenn, hanem egymással szögesen ellentétesek. A historizmus látszólagos tradícionalitásának a valódi, az élő tradícióhoz a maga elvi gyökértelenségében semmi köze nincsen, a probléma megoldását egészen máshol kell keresnünk. És a mondottak értelmében éppen az arisztokrácia volt legkevésbé abban a spirituális helyzetben, hogy ezen segítsen, megoldásán munkálkodjék.

Így egy polgári építtető vagy egy arisztokrata építtető historizmushoz való alapvető kapcsolata azonos volt, csupán az utóbbi anyagi helyzete következtében és gyakran építészeti ismeretei, ilyen könyvek és mintalapok birtokában inkább tudott nagyot, nagyobb szabásút építeni, mint polgári versenytársa.

Itt csak röviden jegyzem meg, hogy - mivel a mondottak értelme a problémának e helyen szükségszerüen túl rövid fölvetése következtében nem, vagy nem egészen világosan jelenik meg - az érdeklődő részletesebben és mélyrehatóbban megtalálja ilyen tárgyú, elméleti célkitüzésủ írásaimban, különösen $A$ historizmus problémája c. problémafelvető kisebb tanulmányomban (Ars Hungarica, 1992/1). Az itteni részletes, pláne kimerítő tárgyalás nemcsak terjedelmi okokból lenne helytelen, hanem - és föleg - azért, mert távol esik a disszertáció egyébként legitim és tartalmilag támadhatatlan célkitüzéseitől. Így a problémafelvetés szintjén való szerepeltetésén túlmenően több nem engedhető meg részemről.

Mielőtt áttérnénk az értekezésnek az egyes kastélyokkal foglalkozó másik felére, még néhány, a teljességre kényszerüen nem is gondoló, rövid megjegyzést sze- 
retnék tenni ehhez a teljesen más jellegü, áttekintő, összefoglaló, analizáló, a hazai kastélyépítészet egészét - az egyes jelenség-, illetve probléma-csoportokat kibontva - kitünően megjelenítő első részére, mely az egyes kastélyoknak az említett alapos második részében szereplő alapos feltárása nélkül persze nem lett volna megírható.

Az 1. fejezetben (Az épittetők világa) elismerést érdemel az építtetők - példákon demonstrált - sokféle motiváltságának gazdagon árnyalt, differenciált bemutatása.

A 2. fejezetben (A tervezés - megbizók és épitészek) - ismét gazdag kazuisztikus anyagra támaszkodva - józanul tárgyalja az arisztokrata építtetők egy rétegének amatőr-tervezői ambícióját, mely olykor bizonyos mértékben szerepet kapott, de a kortárs lelkesedés vagy fitymálás is megjelent, majd ezeknek és időben egyre távolodva újra kritikátlan idézése néha torzításokat is eredményezett, így a kutatókat mindig éberségre intik.

A 3. fejezetben (Az épités és a müszaki felszerelés) szerepel, hogy a kastélyépítésnél számos példa volt jelentéktelen, régi faldarabok megtartásának, vagy egyáltalán a meglevő régi gyakori felhasználásának. Ennek valóban lehettek szimbolikus okai (,ősi fészek”), amelyeket nem szabad eleve és elvből racionalista túlzással megítélni. De szem elől szokták ugyanakkor a kutatók téveszteni azt a sok évszázados, kimutatható józan gyakorlatot, hogy használható mégoly szerény falakat sem dobtak ki, és ez nemcsak a kastélyépítészetben volt így, hanem az építés egész területén. És az „ősi fészek” sem volt mindig az: gyakori volt az adományozás, vásárlás, csere - bár elismerem, belevetíteni, beleérezni más család által épített régi castellumba, kastélyba vagy akármibe is lehet akármit. De gondoljunk Oroszvár barokk cour d'honneur-ös angolos gótizálására (bár itt a családi „ősiség” és a gazdasági ésszerüség egyaránt szerepet játszhatott), vagy arra, hogy a parnói birtokot csak az 1840-es évek második felében vásárolta meg Andrássy Manó gróf fiatalon meghalt atyjának özvegye, és tíz év múltán nagyon is sokat megőriztek a régiből az itt is gótizáló romantikus kastély kiépítésekor. Nem hiszem, hogy e pazar kastélyoknál még dúsgazdag építtetőinek estében is érdektelen lett volna az e nélkül veszendőbe menő anyagi érték.

A 4. fejezet (A stílus) gazdag és differenciált képet ad a felhasznált stílusváltozatokról, elterjedtségük mértékéről. Érthetően teret szentel az újabban használatos „félköríves stílus” terminus mibenlétére, alkalmazásának magyarázatára. Bár ezek főbb elemeiről említés történik, itt határozottan szükségesnek látszik a fogalom viszonylagos újdonsága és szokatlansága miatti részletesebb magyarázat. Különben biztosra veszem, hogy az olvasók nagy részétől bizonyos értetlenség és félreértés is fogja kísérni. Olyan irányú, jellegű módosításra gondolok, mint amilyen $A$ gótizáló romantika Magyarországon c., 1982-ben megjelent írásom 278-279. oldalán található, természetesen e kastély-értekezés ökonómiájához alkalmazkodó mér- 
tékben. Itt ugyanis a romantika stílusirányzatainak átfogó ismertetése keretében a félköríves stílus sokkal részletesebb ismertetése található, mint alátámasztásul a szerző értekezésében hivatkozott (150. jegyzet) tanulmányomban. (E bővített magyarázatban helyet kaphatna az elnevezésnek a szóban forgó „stílus” megjelenésével való egyidejűsége; Ebben Heinrich Hübsch - nagyon gyakran félreértett, vagy nem ismert - szerepe, a „félköríves romantika” részletesebb jellemzése; e fogalomnak a mai angolszász szakirodalomban is megtalálható szereplése stb.)

Az 5. fejezet (A konfiguráció és a tömegalakitás) említi az újkorban felélesztett vitruviusi hagyományok részleges jelenlétét, e jelenlét változatait. Ennek mégoly szerény, a tárgyba belemerülni nem is szándékozó felvetését annyiban tartom jelentősnek, hogy ösztönző lökést adhat annak a historizmussal kapcsolatban lezajló, de korábban kezdődő hanyatlása menetének, jellegének és okainak, majd 19. századi végének kutatására, melynek bekövetkezése, bár csak finom utalásszerüen, hangot is kap.

A 6. fejezetben (Alaprajz, tér, funkció) találkozunk azzal a megállapítással, hogy „ha a kastély urának és úrnőjének a lakosztálya két külön szinten volt, a kettő közé gyakran kisebb, legtöbbször [...] csigalépcsőt iktattak. Hasonló módon a fölépcsőtől függetlenül sokszor (csiga)lépcső vezetett a földszinti közösségi termekből a család emeleti lakosztályába." - Érdemes számon tartanunk, hogy hasonló megoldással találkozhatunk olykor e társadalmi réteg nagyméretủ városi lakóházaiban is, ha azok nem kizárólag bérháznak épültek. - Így Széchenyi István 1847ben a Felső Dunasoron tervezett háromemeletes házában a főlépcső csak a II. emeletig vezetett volna, a többi lépcső a földszinttől a III. emeletig. A III. emeleten lett volna a gróf lakrésze, ahova a II. emeletről egy belső, rejtett lépcső vezetett volna, s ugyanitt lett volna az irodája is. - Ugyanígy csak a II. emeletig vezetett a dokumentáltan 1816-ban épült Szentgyörgyi Horváth-ház (V. Kossuth Lajos utca 3.) fölépcsője az 1850-es évek elején történt átalakításig. (Valószínúleg ez a sajátos körülmény a magyarázata annak, hogy az épület hosszú évekig, évtizedekig mind a szakirodalomban, mind a szekunder irodalom jelentős részében eredetileg kétemeletesnek épültként szerepelt, mely csak Wieser átépítése révén vált háromemeletessé. Így Bierbauer Virgilnél (1925), Vámos Ferencnél (1926), Zakariás G. Sándornál is $(1954,1961)$, vagy a népszerúsítő könyvek hosszú sorába illeszkedő Budapest Lexikon 1993. évi, második kiadásában is).

A 7. fejezet (Az enteriőrök) nemcsak hihetetlenül gazdag és differenciált képet vetít az olvasó elé a historizmus enteriőr kezeléséről, hanem elgondolkodtató terjedelmü volumenét veti fel a megoldandó, talán a historizmuson is túlmutató, problémáknak. A fejezet különös erővel bizonyítja, hogy kellő anyagfeltárás első lépése nélkül agyaglábakon áll minden nagyobb lélegzetű elméleti, eszmei áttekintés, értelmezés. 
E helyen természetesen - bármennyire fantáziát mozgató - nincs terünk részletekbe bocsátkozni, szinte csak felsorolásszerúen támaszthatjuk alá a mondottakat.

Ennek leglényegesebb eleme a romantika történeti, szellemtörténeti értelemben vett hatalmas korszakának három nagy épitészeti áramlatával, a korai gótizálással, a klasszicizmussal és a forradalmi építészettel való eszmei, érzületi és formai rokonsága, olykor szinte hasonlatossága, beleértve ebbe az akkor kibontakozó angolkert - tájképi kert sajátos világát is. (Mindennek tüzetes kifejtését megtalálja az érdeklődő A korai gótizálás Magyarországon c. tanulmányomban [in: ZádorSzabolcsi szerk.: Müvészet és felvilágosodás, Budapest, 1978], de itt képtelenség, túlzás is lenne az ott kibontakoztatott részletességgel e problémáról beszélni annak érdekében, hogy egyértelmúen világossá váljék, mi mindenre gondolok az alábbiakban.)

Figyelmet érdemel az ezekkel kapcsolatos, illetve velük rokon problémák sorában Sisa József helytálló megállapítása, mely szerint a „másodlagos szerepre kárhoztatott falfestés mellett a falképek - a klasszicizmus ilyen irányú érdektelensége után - a historizmus korában előtérbe kerültek" (91. old.). S bár jelenlegi ismereteink birtokában joggal azt állítja a szerző, hogy „összességében azonban nem tünik különösebben jelentősnek a kastélyok belső világában a falképek súlya”, kutatásukat viszont mind „törékeny”, könnyen megszüntethető, divatnak áldozatul dobható stb. mivoltuk miatt, az anyagnak a kastélykutatás várható mennyiségi növekedése eredményeire is számítva, a tudomásunkra jutó nagyobb festészeti anyag birtokában és alapján a nagyobb összefüggések megismerésének jogos reményében fontos , ,uj" feladatnak tekintem.

Igen fontos a szerzőnek a bútorok elhelyezési formájával kapcsolatos mondanivalója. „Nagy vonalakban tekintve [az e téren bekövetkezett] változás úgy írható le, hogy míg korábban a bútorok zöme a terem falai mentén helyezkedett el, a historizmus korában a faltól eltávolodva a helyiség közepe felé mozdultak el. Az asztalok és székek a terem egyes pontjain szabálytalanul elhelyezett csoportokat képeztek, ami a kötetlen és kényelmes enteriőr érzetét fokozta. [...] Ez az elrendezés [ugyanakkor] tekinthető a korban divatos, szabálytalanságot és esetlegességet sugalló facsoportokkal élénkitett tájképi kert sajátos leképezésének is." (96. old.) A szerzőnek ez a nagyon finom és nagyon fontos, ha szabad azt mondanom következményekkel terhes megfigyeléséhez hozzátartozik, hogy ugyanígy volt lényegében a romantika korában a 18. század második felétől kibontakozó tájképi kertnél már száz évvel korábban is. Ez már utalás arra, hogy a historizmus szellemi gyökerei sokkal szélesebb idősávban helyezkednek el, mint a szoros értelemben vett és e disszertációban tárgyalt historizmus.

Ehhez kapcsolhatjuk a parasztszoba 98. oldalon említett újdonsült kultuszát, mely „beleillett egyrészt az egzotikumot, a különleges világot megjelenítő enteriőrök hagyományába [...]” (98. old.) Miként, ha búvópatakként is, „de az orien- 
talizáló - kínai vagy japán stílusú - bútor és berendezés a historizáló kastély enteriőrkialakításában szintén jelen volt [...] (98. old.)

De a korai gótizálás világával rokonnak tekintem azt is, ahogyan alkalmilag a „mürom”-készítés mentalitásához közelítenek. Ahogyan a szerző írja: az „enteriörök egy részét olyan módon alakították ki, hogy régi épületekből származó felszerelési tárgyakat, illetve épületrészeket foglaltak bele". (92. old.) Gondoljunk ezzel kapcsolatban a Charles de Moreau tervezte, 1801-ben épült tatai múromra, melybe - egyebek mellett - római köveket és az egykori vértesszentkereszti templom finom gótikus kőfaragványaiból foglaltak be maradványokat.

A historizmus kastélyépítészetének stiláris szemléletét, de az egész akkori építészetet a mélyben jellemző sajátságok közül még idézem: „A homlokzati architektúrától való eltérés, illetve egy épületen belül a termek közti stiláris anyaghasználatbeli különbség a belső térdíszítés autonómiáját jelzi, ami akár az egyes helyiségek szintjén is jelentkezhet" (89. old.). Ez, stiláris szinten, a szervesség helyett a külsőleges, mesterséges additív szemléletről tanúskodik, a romantika korszakának három nagy építészeti áramlatához kapcsolhatóan.

Minderről egészen röviden, összefoglaló jelleggel: a romantika és a historizmus kapcsolata eddig sem volt titok. De a jelenség mibenlétének a legmélyebb alapokig leásó feltárása még feladatunk, miként az egész jelenség történeti egyszeriségének hiteles kibontása szintén. Ennek megvalósításához ad ez az értekezés ösztönzést és hatalmas, de még így is tovább bővítendő kazuisztikus anyagot. Ez egyike fó erényeinek.

A további négy fejezet (8. A környezet: melléképületek, park, település; 9. Élet a kastélyban; 10. Müvészet és tudomány; 11. Reprezentáció és nyilvánosság) - A 8. kivételével, amely főleg a historizmus kastélyparkjai jellemzését tárja Sisa Józsefnek, a téma avatott szakértőjének megformálásában elénk, és ezeknek a korszakon végighúzódó különböző változásairól nyújt differenciált képet, a többinek témája erősen szociológiai természetü - ezért azok részletes tárgyalása az ezzel foglalkozó opponensi véleménytől várható. Velük kapcsolatban tehát csak néhány, elsődlegesen művészettörténeti érdekủ megjegyzésre szorítkozom.

Így mindjárt szót ejtek arról a körülményről, hogy az építészettörténet számára korábban szinte teljesen ismeretlen kerttervező-attribuálások nyomán, miként ez azért várható volt és már jelentkezik is, egyre több kastélypark tervező személyének megismerésére van kilátásunk. Ilyen használható, igen hasznos forrás például idősebb Pecz Ármin (1820-1896) jeles kertészünk kéziratos önéletírásának (238 tételes) saját életmü-jegyzéke. Ezt nem jelen értekezés hiányaként hozom szóba, hiszen e forrás létezésének ismeretét éppen Sisa József lekötelező szívességének köszönhetem, kinek számára a hatalmas forrásanyag kritikai feldolgozása, de még kézbe vétele is, nagy müvének készítése idején - amelyhez ez nem is volt elengedhetetlenül szükséges - aránytalan munkát jelentett volna. Jellemzésül, kiragadva 
csupán jelzem, hogy például Pecz Ármin tervezte és valósította meg a vele többször dolgoztató Bukovics Gyula által tervezett (218.) old.) turai Schossbergerkastély parkját, melyet ugyan az értekezésben szereplő forrás Jámbor Vilmos nevéhez köt. (Ez mutatja, hogy az említett kritikai feldolgozás mennyire elengedhetetlen!) Jegyzékében még saját nevéhez füzi Pecz Ármin a budai Karácsonyi-palota parktervét, a pilismaróti Heckenast-villa háromszintes tájkertjét vagy a Hunyadi János úti romantikus Reitter-ház aprócska belső kertjét.

$\mathrm{S}$ ha már Pilismarót szóba került, hadd említsem meg, talán érdemes lenne a szerzőnek megfontolnia, hogy valamilyen formában szóba hozza legalább az igényesebb, méretei következtében is számításba vehető villákat, s azok nézete szerinti viszonyát a kastélyépítészettel kapcsolatban. Hiszen ilyen utalásokról szétszórtan van is több helyen szó a disszertációban. Ilyen volna a pilismaróti Heckenast-villa, a budai egykori Frievaldszky-, a sashegyi Weber-villa vagy a szombathelyi Bagolyvár épülete - és még sok más is, amelyeket a szerző épp oly jól ismer, mint az említetteket. - Ha a mondottakat elfogadhatónak tartja, meg vagyok győződve, kimunkálásával jó alapot fog szolgáltatni a nem mindig egyértelmúen elkülöníthető villák kutatására, esetleg azok bizonyos mennyiségének, rétegének, fajtájának (értelmezést is gazdagító) abszorbeálására. - Ugyanakkor tisztában vagyok azzal, hogy ha van is a kastély és a villa között távoli rokonsági kapcsolat, a villák világa mindenképpen önálló müfajt képvisel.

Az értekezés - bibliográfiát, építész-ismertetéseket, összefoglaló kimutatásokat stb. tartalmazó részét leszámítva - két, nagyjából azonos terjedelmú egysége közül az első az érdemi feldolgozást jelentő áttekintést és elemzéseket tartalmazza. Eddigi észrevételeim ezekkel foglalkoztak. A második nagy egység az egyes kastélyok sorából kiválasztott 83 épületet tárgyalja a monografikusság valamilyen szintjén, számos esetben a szerző saját, olykor mások kéziratos vagy publikált alapvető monográfiájára támaszkodva. Ezeket kiegészíti a mai látószögünkből áttekinthetô és a mü léptékében vagy problémakezelésében említést igénylő kastélyok teljes jegyzéke, a „monografikus” részben nem szereplök esetében is közölve a rájuk vonatkozó néhány alapvető építési adatot.

Bár az értekezés alapvető és mindenre kiterjedő tudományos megállapításait a mủ első egysége tartalmazza, ez nem jelentékteleníti el a második egység (bizonyos szempontból akár fontosabb), a „mini-monográfiákat” tartalmazó részét. E történeti alaprétegnek mintegy felszántása nélkül a szerző nem lett volna abban a helyzetben, hogy az első egységben található feldolgozást elvégezze. És azt is tudnunk kell, hogy a két nagy rész anyaga, adatai, megállapításai adatszerủ részletességgel is összefüggenek, egyik a másik nélkül nem lenne ugyanaz. Sőt, a kettő még számos megállapítás, értelmezés és értelmezhetőség szintjén is - együtt képviseli a mü címében foglalt mondanivalóját. 
Érthető továbbá, hogy e terjedelmes és egyébként gondosan, alaposan elkészített monografikus részhez a dolog természetéből következően, az opponensi állásfoglalás szintjén nem sok megjegyezni való van, azok felvetése inkább egy leendő könyvkiadás szolgálatában, majd készülő lektori véleményben indokoltak.

A kevés szóba hozni szándékozott momentum között megemlítem, hogy az építkezések tárgyalásánál többször találkozunk azzal a megállapítással, hogy „, $a z$ épitkezést ez és ez az épitómester irányitotta”. Ismerve a 18-19. század építőgyakorlatát, helyesnek azt a formulát kell tekintenünk, amelyikkel például a kajdacsi Sztankovánszky-kastélynál találkozunk: „A kastély kivitelezését Wittinger Sándor tolnai épitömester végezte." (250. old.)

Míg a tóalmási kastélyról (nyilván helytállóan) azt olvassuk, hogy „az épület terveit a Nay és Strausz budapesti épitész-társulás készítette (262. old.), a katymári Latinovics-kastélynál csak azt találjuk, hogy ,az épület terveit Gerster Károly és Kauser Lipót pesti építészek készítették" (167. old.), holott itt is társulásról volt szó.

Míg ez a két megjegyzés, ha az írás igényes megmunkáltsága szemszögéből nézve nem is érdektelen, azért nem sokkal emelkedik a lektori szempontú gondosság szintje fölé.

De jelentősebb probléma felvetésére - nem fogyatékosság regisztrálására! nyújt lehetőséget a nagyugróci kastélynál található egyik jelenség. A kastély lépcsőházának gótizáló díszítményein a magyar emlékanyagban eddig alig talált, minden modellálás nélküli, lelapított, mintegy lombfürésszel kivágott formálás látható - ami a kastélyépítészetben egyelőre még unikumnak is számít. Bár e kastély díszítményeinek egy részén látható a korai gótizáláshoz némi közelségben lévő formálás, ezek mibenléte a szempontunkból kicsinek számító (a Pichlmonográfiában ráadásul jóval bővebben is szereplö) képanyagról nem olvasható le. - Ilyen préselt virágra emlékeztető díszítmény-formálásról magam még két helyen tudok: a pétervásári templom kórus alatti boltmezőinél (1812-1817) és a beregszászi rk. templom homlokzatán (1836-1847).

Bár mind a gyakoribb, puha modellálású, mind a „lepréselt” gótizáló tagozatok a korai gótizálás kellékeként jelentek meg nálunk, egyre inkább úgy tünik nekem, hogy a kortársak által „csehízlésűnek” nevezett stílusáramlat mintegy önállósította magát, és a korai gótizálás periódusát túlélve a romantikus historizmus gótizáló változatát később is így jelenítette meg, mindaddig, míg az ilyen képzettségű mesterek (esetleg tanítványaik) és az ezen ízlésvilágban felnőtt építtető réteg aktív volt.

Feltünő továbbá ezeknél a Felvidéken eddig ismert gyakoriság és ezekben a cseh-morva származású vagy azokhoz közelálló mesterek részvétele (Buck József, Povolni Ferenc, Zach János, a magyar-morva határvidéken tevékenykedő Császtka család). 
Bár a Pichl-monográfia közel tíz éve jelent meg, s alkalmat nyújtott e problémára való felfigyelésre, jelen újra felmerülése és nagy anyagban való (legalábbis egyelőre) társtalan jelenléte, egyéb újabb ismereteink birtokában ösztönzést adhat ennek az egyáltalán nem érdektelen részletproblémának alaposabb vizsgálatára.

Mielőtt azonban rátérnénk a végső értékelés záró szavaira, szeretném még, mintegy összefoglalásul az értékelés jellegének két fontos sajátosságát megemlíteni. Mint láttuk, e munka elsőként vállalkozik arra, hogy a sokat vitatott historizmus egy monumentális múfajának, a kastélyépítészetnek igen széles bemutatását elkészítse. Mint a szakirodalom ismeretében tudjuk, a historizmus tüzetes megismerésében az értékprobléma megoldása és a történeti kép felkutatása, megrajzolása ahogyan az többé-kevésbé mindig történt - párhuzamosan haladva, de külön-külön valósul meg, és ez elvben, alapvetően, helyes is. De kevés olyan munkálkodás nyújt olyan értékes anyagot az értékprobléma vizsgálata kezébe, mint a monumentális múfajok sorába tartozó alkotások feltárása és bemutatása. - Ugyanakkor e disszertáció ugyanazon sajátságai nyújtanak majd talán minden eddiginél szélesebb alapot, gazdagabb anyagot a historizmus jellemző, alapvetően ideologikus jellegünek tekinthető stílusválogatása szabatosabb értelmezésére és múvészeti magyarázatára, értékelésére; a 19. századi neostílusok általam módusokként való kezelése helyességének vizsgálatára.

Így ez az értekezés - remélhetően belátható időn belül: könyv - ezért is, ettől függetlenül is az eljövendő évtizedek számára sokáig érvényes keretet és vázat fog nyújtani születendő monográfiák, feldolgozások számára. És így várhatóan sokáig kibontakoztatásra predestinált alapmúnek fog számítani a maga területén. - Tudatában kell persze lennünk annak, hogy egy ilyen anyaggazdag és átgondoltan kidolgozott munka igazi belső feldolgozása, szilárd képet kibontakoztató megemésztése sok időt és energiát igényel, többet, mint a mégoly hosszadalmas opponensi vélemények első felmérést jelentő bemutatása. Külső feldolgozása viszont a megkezdett munka talán soha le nem záródó folytatása, minden vonatkozásban való kibontakoztatása kell, hogy legyen.

Szerzője eddigi gazdag munkásságának ezzel a szép megkoronázásával méltó az akadémiai doktori cím elnyerésére, amit formálisan is a legmelegebben ajánlok.

\section{SISA JÓZSEF VÁLASZA GYÁNI GÁBOR, KOMÁRIK DÉNES ÉS WINKLER GÁBOR OPPONENSEK VÉLEMÉNYÉRE}

Először is megköszönöm opponenseimnek, hogy értekezésemet behatóan tanulmányozták. Köszönöm a méltatást, és köszönöm a kritikus észrevételeket is, melyek további szempontokra és adatokra hívták fel a figyelmet. A válaszomban együttesen kívánok reagálni opponenseim felvetett kérdéseire, mivel közülük több 
ugyanazon vagy egymással rokon témát érint, illetve egyes más kérdéseknél külön konkrét választ szeretnék megfogalmazni.

Mindhárom opponensem a véleményében foglalkozott a stílus kérdésével, pontosabban a historizmus problematikájával, ami a disszertáció egyik alapvető tézisét érinti. A historizmus olyan komplex jelenség, amelynek mélyebb analízise még folyamatban van; definiálása, áramlatainak azonosítása, korszakhatárainak a meghúzása, sőt akár terminológiai megjelölése ma is kérdéseket vet fel. Hogy a probléma mennyire aktuális, jelzi a fóti templom évfordulója kapcsán a közelmúltban lezajlott romantika-konferencia, ahol például az egyik opponensem, Komárik Dénes a barokkos stílusjelenség új aspektusaira hívta fel a figyelmet. Az értekezésemben a historizmus problematikáját természetesen nem taglalhattam teljes mélységében, mindössze azt célozhattam meg, hogy az általam leginkább relevánsnak tekinthető kereteket felvázoljam, abban végig kövessem azokat a tendenciákat, modusokat, amelyek a korszak magyarországi kastélyépítészetében valamilyen szerepet játszottak, valamint kimutassam a specifikumokat, amelyek a múfajra sajátosan jellemzők. A gondolatok és divatok felfokozott áramlásának korában a magyarországi fejlemények természetükből fakadóan lényegében az európai fejlődés leképezését jelentették. A „történeti stílus tobzódásának logikája” - hogy Gyáni Gábor opponensem kifejezésével éljek - alapvetően ebben az európai kontextusban keresendő, ahol az egyes stílusáramlatok mint valamely fúga egymás után belépő szólamai jelentek meg. Az áramlatok jellemzésén, eredetük meghatározásán és magyarországi jelenlétük bemutatásán túl, ahol lehetett, igyekeztem egyes kastélyoknál megragadni családi, személyes vagy regionális elemeket. Ilyen volt pl. a Nádasdyak angol stílus-választásának családi legendáriumban gyökerezése, a franciaországi példák szerepe személyes élmények alapján Andrássy Gyula tiszadobi vagy id. Pálffy János bajmóci kastélyában, vagy éppen az erdélyi hagyomány mint regionális elem felidézése Teleki Géza pribékfalvi kastélyában. Arra is utaltam, hogy az építtető háttere, társadalmi státusza egyes esetekben ugyancsak szerepet játszhatott a stílusválasztásban: ilyen értelemben utaltam néhány olasz neoreneszánsz stílusú épületre, mint Kégl György csalai vagy báró Lévay Henrik pér-táplánypusztai kastélya. Az egyes családokon belül fellelhetô stíluspreferenciára a Kendeffyeknél találtam példát, ahol két családtag egymással párhuzamosan, hasonló stílusban épített Őraljaboldogfalván és Kernyesden. Az, hogy ezeket az adatokat a stílusról szóló alfejezetben, vagy a vonatkozó kastély-minimonográfiákban tárgyaljam, mindig eseti döntés kérdése volt. Mérlegelnem kellett ugyanis, hogy valamely általános jelenségről van-e szó, vagy pedig egyedi és kevésbé általánosítható esetről. Ez egyébként nemcsak a stílus tárgyalását, hanem az értekezés több más alapegységét is érintő kérdés volt: dönteni kellett, mikor beszélhetünk egyedi jelenségekről, és mely ponttól lehet azok száma és súlya alapján már vala- 
mely típust megkülönböztetni. A tárgyalás során bebizonyosodott számomra, hogy a két kategóriát gyakran meglehetősen vékony vonal választja el egymástól.

A fenti eszmefuttatás vonatkozik a reprezentáció jegyeinek megítélésére is: el kellett dönteni - és mint hasonló esetekben, az adott döntéssel nem feltétlenül ért egyet minden szakember -, mely elemek tekinthetők megfelelő számú példával alátámasztott, általánosabb érvényű jelenségnek, és melyek minősíthetők pusztán egyes épületek sajátosságának. Mivel itt épület-ikonológiai kérdéséről van szó, bizonyos tipikusnak minősíthető jegyek kiválasztása és értelmezése látszott a célravezető útnak. Úgy gondolom, hogy azok a tényezők, amelyekről a munkámban említés történik, vagyis például a torony szerepe és jelentése, a heraldikai elemek és motívumok felmutatása, az ős-kultusz eszközei, a kastély irányulása környezetéhez mind olyan elemek, melyek a reprezentációt a kastélyokban elsődlegesen szolgálják. Azt viszont készséggel elismerem, hogy a probléma - akárcsak elvileg bármely felvetett kérdés - továbbgondolásra érdemes.

Hasonló, az egyediséget és az általánost érintő megfontolások jöttek számításba az alaprajzi tipológia tárgyalásakor. Az alaprajzi és téralakítási elemzésnek nagy fontosságot tulajdonítok, és ezt igyekeztem az értekezésben érvényesíteni. Munkámban mintegy 50 alaprajzot és néhány további helyszínrajzot szerepeltettem, melyek részben egykorúak - legyenek azok eredeti tervrajzok vagy kortárs szakpublikációkból átvett ábrák -, részben újabb eredetü felmérési rajzok. Ezeket az alaprajzi rendszerek vizsgálatánál igyekeztem mind figyelembe venni. A kérdés, hogy melyik alaprajzi megoldások egyediek, illetve melyek alkotnak számuk és jellemző alkalmazásuk jóvoltából típusként is leírható nagyobb csoportot, sokszor dilemma elé állította a szerzőt. Ugyanakkor tudom, hogy az építész képzettségü szakember, mint például opponensem, Winkler Gábor érzékenyebb, ha úgy tetszik iskolázottabb szemú ezen a területen. Az általa felvetett további alaprajzi megoldások típusként való értelmezésének a lehetőségét elfogadhatónak tartom, illetve az erre vonatkozó kiegészítő megjegyzéseit köszönettel veszem. Hogy az alaprajzi tipológia kategóriáinak meghatározása, szempontjainak érvényesítése a sajátos magyar viszonyokra vetítve nem egyszerü feladat, az abból is származik - ahogy Komárik Dénes véleményéből is kiolvasható -, hogy a hatalmas mennyiségi és minőségi produktumot felmutató magyar historizmus egyetlen más építészeti múfajáról sem készült hasonló mélységú és terjedelmű feldolgozás.

A gazdasági háttér kérdését opponensi véleményében Gyáni Gábor vetette fel. Az értekezésem vonatkozó részében igyekeztem a rendelkezésre álló és végül is nem csekély számú adatokat összefoglalóan értelmezni, tudván, hogy ezek minden igyekezetem ellenére messze vannak a teljességtől. Érthető, hogy e vonatkozásban a bírálómban némi hiányérzet maradt. Szeretném azonban felhívni a figyelmet a tárgyalt korszaknak az értekezésben is kiemelt sajátosságára. A 19. század második felében a kastélyok kivitelezésében maguk az uradalmak már alig játszanak 
szerepet, a munkálatok immár a városi építési gyakorlathoz kapcsolódnak. Ennek megfelelően vonatkozó dokumentumok érdemben már nem az építtető család levéltárában, illetve nem az uradalmi iratokban remélhetők, hanem elméletileg a kivitelező építőmester vagy cég archiváliái között. Ezek azonban ismereteim szerint jóval csekélyebb arányban maradtak fenn, mint mondjuk az arisztokrata, illetve nemesi levéltárak. Talán azt sem túlzás állítani, hogy kivételszámba megy valamely kastélyt építő vállalkozás iratainak közgyüjteményben történt fennmaradása. Feltehető, hogy e területen csak a következő évek, illetve évtizedek kutatása fog kézzelfogható eredményt hozni. Ezzel kapcsolatban példaként szeretném megemlíteni a lakberendezéssel foglalkozó Schmidt Miksát, akinek igen tetemes, Bécsben és Budapesten örzött terv- és iratanyagának feldolgozása néhány éve kezdődött. Eddigi ismereteink szerint Schmidt nem egy kastély belső kialakításában müködött közre, amire értekezésemben utaltam, és a hagyatékot kutató-feldolgozó kolléga jóvoltából erre vonatkozó illusztrációt szerepeltethettem. Az anyag teljes feltárása és szempontunk szerint történő értékesítése önmagában is igen számottevő vállalkozás lesz.

Szeretnék megemlíteni ehhez kapcsolódva egy érdekes jelenséget. Számos 18. és 19. századi kastélyt kutatva - most eltekintenék tételes felsorolásuktól - azt tapasztaltam, hogy a családi levéltárakban a kastélyokra vonatkozó iratok mennyisége az 1850 utáni időszakból érezhetően megcsappan. Ez vonatkozik az uradalmigazdasági iratokra, de az egyéb iratokra is. A jelenséget észleltem a különböző korszakban épített kastélyok kutatásakor, de akkor is, amikor pl. egy kastély történetét több korszakon keresztül próbáltam végigkövetni. Ez azt jelenti, hogy nem egyszer könnyebben és bővebben fértem hozzá a barokk vagy klasszicista korszakban épített kastélyok levéltári dokumentumaihoz, mint a historizáló épületekéhez. Nem egyértelmú számomra, hogy ennek oka az ügyvitel sajátosságaiban, az iratok őrzésének módjában vagy éppen az adott esetekben a II. világháború utáni pusztulás formáiban keresendő. A levéltári archiváliák relatív szükössége mellett viszont szerencse, hogy éppen a század közepén, illetve harmadik harmadában jelennek meg nagy mennyiségben másfajta, éspedig nyomtatott és képi források, amelyek a kastélyok beható kutatását jelentős mértékben elősegítik.

A fenti fejlemények tükrében érdemes értelmezni a historizáló kastélyok enteriőrjeinek kérdését. Először is kiemelésre kívánkozik, hogy a korszak kastélyépítészet-kutatásának e szegmense rendelkezik talán a legkevesebb előmunkálattal. Ennek okát legalább annyira lehet az ez iránt csak mostanában kibontakozó érdeklődésnek, mint az emlékanyag igen nagyfokú pusztulásának betudni. A vonatkozó magyarországi emlékek valamilyen fokú összegyüjtése, az értékelés szempontjainak kimunkálása tehát az értekezés számára mindenképpen úttörő feladatot jelentett, még ha ez irányban egyes épületek monografikus feldolgozásában én is, és a témával foglakozó néhány más kollegám is tett már korábban lépéséket. Minthogy 
egy meglehetősen illékony müfajról van szó - a belső helyiségek felújítása, a bútorok átrendezése, a tárgyak kicserélése a divat és az egyéni igények nyomán könnyedén megvalósítható volt, és a kastélybelső generációnkénti modernizálásával is számolni kell -, a kutató meglehetősen ingoványos talajon mozog. Természetesen tudatában vagyok annak, hogy erre vonatkozóan a kastélyleltárak értékes támpontot nyújthatnának. Ezt saját gyakorlatomból is tudom, hiszen nem egy régebbi építésủ kastély kutatásánál ilyenekkel találkoztam, ezeket publikáltam, illetve igyekeztem értelmezni. Volt olyan eset, amikor valamely kastélynak több, különböző korszakban összeállított leltárát fedeztem fel. Viszont a probléma egyelöre éppen a leltárak hiánya, pontosabban feltáratlansága a historizmus korszakából. Az általam levéltári mélységben kutatott kastélyoknál ilyen sajnos nem került elö. Ennek fényében komoly forrásértékkel bírnak a századfordulóra megszaporodó enteriőr-fotók, melyek szerencsére a mai napig nagy számban állnak rendelkezésre. (Zárójelben hozzá kell tenni, hogy sajnos Magyarországon nem volt meg az enteriőr-rajzolásnak a kultúrája, ami pl. Angliában oly sok információt szolgáltat a korábbi korok lakáskultúrájáról.) A fényképek által nyújtott vizuális élmény is felülmúlja a lajstromok száraz bejegyzéseit. Természetesen tudom, hogy a fényképek relevanciája is korlátozott, több ok miatt. Az egyik ok, hogy csak a 19. század utolsó évtizedeitől lehet számolni velük, tehát a korábbi állapotokra nézve - ha ilyenek kastélybelsőkről egyáltalán készültek - csak részben és fenntartással használhatók. Ezen kívül valóban valamilyen szögből rögzítik az adott teret, ami által a tárgyak elhelyezkedése ugyan követhető, de teljességük nem rekonstruálható. Hiányosság továbbá, hogy az alárendelt, szerényebb kialakítású helyiségekről alig, vagy egyáltalán nem készült fényképfelvétel. De a fotókon kívül van még egy forráscsoport, amely ha nem is pótolja a leltárakat, igen komoly forrásértékü. A kastélybelsők leírásáról van szó, melyekből - hála a korszakbeli publikációk minden korábbinál nagyobb bőségének és változatosságának - meglehetősen sok áll rendelkezésre. A leírások lelőhelye éppúgy lehet honismereti munka, képes újságcikk, szakfolyóirat közleménye, memoár, mint éppen - általános jelleggel - szépirodalmi munka vagy a témába vágó gyakorlati kézikönyv. A kastélyok mini-monográfiájában ezekből nagy bőséggel idéztem, és a levonható tanulságokat az általános analízisben is igyekeztem érvényesíteni. Ez természetesen nem jelenti azt, hogy a jövőben nem kéne törekedni az ilyen irányú levéltári források feltárására és hasznosítására.

Az értekezésemben a tárgyalás középpontjába magát a kastélyt állítottam. Az épület történeti, stiláris, alaprajzi, technikatörténeti vizsgálata alkotja a disszertáció törzsét. A további más aspektusok, mint például az enteriőr-múvészet, a környezet és a kertmúvészet, valamint a számos gazdasági, szociológiai, kultúrtörténeti vetület tárgyalását azért tartottam fontosnak, mert ezek segítségével lehet ezt a jelentős épülettípust szélesebb kontextusba helyezni, az épületet mint társadalmi 
jelenséget is értelmezni, s ezáltal a szükebb építészeti, illetve építészettörténeti megközelítést újabb dimenziókkal gazdagítani. Az említett témák kidolgozása azonban az értekezésben szükségszerủen sommás, egyrészt a helyesnek vélt arányok megtartása céljából, másrészt a vonatkozó kutatás viszonylag kezdeti állapota miatt. Egyértelmű, hogy ezen aspektusok egyenkénti, teljes kidolgozása önmagában is megérne egy-egy önálló disszertációt.

A fenti megfontolások alapján tudok válaszolni opponenseim néhány további felvetésére. Winkler Gábor kérdezte, hogy nem lett-e volna helyes a tárgyalást lineárisan vezetni, vagyis úgy, hogy a nagyból a kicsi felé haladva a környezettel és a kerttel kezdjem az elemzést, és csak ezután következzen maga a kastély. Megvallom, ez a lehetőség kezdetben bennem is felmerült, de végül az imént említett okok miatt a szorosan a kastélyépülettel foglalkozó részegységeket tettem a tárgyalás első, fő tételévé, és minden egyéb csatlakozó melléktémát ez utánra helyeztem. Egyébként ez az eljárás nem idegen a magyar és nemzetközi szakirodalmi gyakorlattól, ahol rendszerint előbb a kastély, majd a kert tárgyalása következik.

A kastélyvilág kulturális és szociológiai aspektusainál sem tudtam törekedni teljességre, inkább a főbb jelenségek léptékarányos felvázolására, kontextusba helyezésére vállalkozhattam. Emiatt tünhet úgy, hogy pl. a kastélyban őrzött könyvgyüjtemények és levéltárak tárgyalására nem fektettem elég súlyt, aminek a pótlását egy későbbi publikáláskor mindenképpen megfontolnám. A kastélyélet szereplőinek személyét, mindennapjait, kétlakiságuk vagy állandó helyben-lakásuk mikéntjét szintén a fent jelzett arányokban volt módom bemutatni.

A forráskritikával igyekeztem körültekintően eljárni, de a jelek szerint ez nem minden esetben sikerült maradéktalanul. Ami a Gyáni Gábor által említett, gróf Károlyi Istvánról szóló passzust illeti, miszerint a szóban forgó arisztokrata - és most idézem a korabeli szöveget - „,derék, daliás fóúr, elegáns gavallér, jó gazda, a ki épp ugy otthon van a mezőn, az erdőben, mint a szalon parkettján; kitűnően kezeli a fegyvert, jól üli meg a lovat" stb., ezt igyekeztem a kastélytulajdonosról alkotott kortárs ideálképként bemutatni, és semmiképpen sem tekintettem árnyalt jellemrajznak. Úgy tűnik, e vonatkozásban a megfogalmazásomnak még kritikusabbnak és távolságtartóbbnak kellett volna lennie.

A fenti eset egy általános kérdést is jelez. Éspedig azt a mai napig létező ambivalenciát, amely a nemesség, és különösen az arisztokrácia társadalmi szerepének az értékelését jellemzi. Ahogy imént hivatkozott opponensem is elmondta, e társadalmi osztályt a 20. században alapvetően negatív megítélés sújtotta, de hozzá kell tenni, hogy egyes korábbi korszakokban az arisztokratákat mint nemzetietlen réteget ugyancsak megbélyegezték. Ezzel szemben a róluk szóló egykorú írások és utalások jelentős részének hangnemét a kritikátlanul pozitív beállítás, nem egyszer a hízelkedés jellemzi. Ehhez járul az utóbbi évtizedekben külföldön és Magyarországon viszonylag nagy számban megjelent memoároknál jelentkező apologetikus 
hangnem. Vagyis különös figyelmet igényel a múlt objektív és elfogulatlan megközelítése, a tények gondos és hideg fejü mérlegelése, hogy a kutató a mindkét irányból rá leselkedő előítéletektől tudatosan távol tartsa magát. Ez alapvetően fontos annak az építészeti múfajnak a tárgyalásánál, amely lényegében a nemesi, illetve arisztokrata kultúra és életforma keretét adta.

Gyáni Gábornak az értekezés apparátusát illető megjegyzéseivel elvileg és alapvetően egyetértek. Vagyis minden hasonló léptékű munkát érdemes gazdag és sokrétủ apparátussal felszerelni, hogy a tárgyalt, nagy volumenú anyag faktuálisan, akár számszerüsítve is minél jobban értelmezhető legyen. Az értekezés apparátusának legfontosabb egysége nézetem szerint a kastélyok jegyzéke. Ebben alfabetikus rendben sorakoztattam fel több, mint 600 kastély adatait; a címsorok egységes rendszerben tartalmazzák a földrajzi meghatározást, az építtető nevét, ha ismert: a tervező nevét, az építés idejét, a vonatkozó esetekben a több építési periódust, és ahol szükséges, az építés jellegét (átépítés, bővítést stb.). A jegyzékben félkövérrel vannak kiemelve azon címsorok, amelyek a mini-monográfiák sorában tárgyaltatnak. A disszertáció második nagy egységében egyébként a mini-monográfiák hozzávetőlegesen kronologikus rendben követik egymást. Emiatt tekintettem el a részletesebben tárgyalt kastélyok kronologikus jegyzékétől. A szóban forgó kastélyok térképen való szerepeltetése ugyanakkor valóban jól érzékeltetné földrajzi eloszlásukat, ennek elkészíttetését a publikálás esetében mindenképpen megfontolandónak tartom.

Válaszom végén szeretnék köszönetet mondani. Először is munkahelyemnek, az MTA Művészettörténeti Kutatóintézetnek, amely a több évtizedes munkához megadta az intézményes keretet és támogatást. Mindazon számos kollegámnak is, akik szakmai vagy gyakorlati segítséget nyújtottak. Levéltárak, könyvtárak és múzeumok szakembereinek, és sok mindenki másnak, akik valamilyen formában segítettek. És végül, de nem utoljára hálával tartozom családomnak, akik a munkámban szóval és tettel mindig mellettem álltak. 